\title{
The Development of an Instrument to Carry out Clinical Interviews Easily as Well as Medical Recommendations in Nahuatl in Mexico
}

\author{
Nelson Eduardo Alvarez Licona*, María de la Luz Sevilla González, Eduardo Alvarez Sevilla, \\ Ricardo Alvarez Sevilla
}

Superior School of Medicine, Instituto Politécnico Nacional, Mexico City, Mexico

Email: *nalvarez@ipn.mx

How to cite this paper: Alvarez Licona, N. E., Sevilla Gonzalez, M. L., Alvarez Sevilla, E., \& Alvarez Sevilla, R. (2018). The Development of an Instrument to Carry out Clinical Interviews Easily as Well as Medical Recommendations in Nahuatl in Mexico. Advances in Anthropology, 8, 127-139. https://doi.org/10.4236/aa.2018.83007

Received: April 13, 2018

Accepted: August 25, 2018

Published: August 28, 2018

Copyright $\odot 2018$ by authors and Scientific Research Publishing Inc. This work is licensed under the Creative Commons Attribution International License (CC BY 4.0).

http://creativecommons.org/licenses/by/4.0/

cC) (7) Open Access

\begin{abstract}
This document shows the mechanism and logic which were used to develop the communicative instrument. This instrument will facilitate the communication between the health personnel and the Nahuatl population in Mexico. Using this instrument, clinical interviews, as well as medical recommendations may be carried out despite the lack of knowledge of the Nahuatl language. The instrument was developed taking in consideration that Nahuatl is a tone language in comparison with Spanish grammar. Regarding phonetics, it can be read since it shares the same alphabet. The knowledge of this language was required to decide the use of the polite language instead of the reverential language which is more complicated. This document is based on the field research, the clinical interviews done by the internists, as well as the clinical experience of doctors who were responsible for the medical recommendations. Both the clinical interview and the medical recommendations are presented for the application as well as additional documents such as dictionaries and compendiums.
\end{abstract}

\section{Keywords}

Communication, Nahuatl, Clinical Interview, Medical Recommendations, Language

\section{Introduction}

"Languages take into account syllables, intonations, pauses, how people use them, the physical and emotional effort that each word, phrase, and paragraph require which there is no way to avoid, overlook or set aside: without them, any language is impossible" (Henestrosa, 1993: p. 14). 
This document shows the mechanism and logic of the development instrument that may facilitate the communication between the native speakers and non-native speakers of Nahuatl in the health sector. It may be useful for the clinical interview as well as the medical recommendations in Nahuatl in Mexico.

The health personnel faces a communication problem when they try to talk to Nahuatl-native speakers because of their lack of knowledge of the language. It is difficult for them to carry out the clinical interviews and the medical recommendations. In these communities, indigenous languages are used for communication in regular basis. Since it is difficult for the health personnel to carry out the clinical interview and the medical recommendations, they need a translator of the community who speaks both Spanish and Nahuatl. The Health Care System does not have a translation department for communicative support with the Nahuatl speakers for our research.

In such conditions, the health personnel, in charge of this task, uses the available resources. For instance, they normally are supported by bilingual workers of the community, particularly, workers from the health center who support in the translations of the clinical interviews, medical recommendations, or the prescriptions. There are cases in which the patient goes to the doctor with an "improvised" translator. In most of the cases, the so-called translator might be a relative or a close person of the patient.

This difficulty (regarding clinical care) raises questions, such as if the translator actually translated everything that has been said, if the meaning of the communication was kept, and if the patient's answers were not lost in the translation. The lack of professional translators makes that the quality of this service is not as good as it should be; firstly, the respect of the patient's rights: it is difficult to make a dialogue based on the evidence that comes out from the clinical interview in addition to the prescription as well as the medical recommendations that the patients require. This is the reason why this instrument will enable the health personnel to do the clinical interviews as well as the medical recommendations in the indigenous language, in this case, for Nahuatl, even though they do not speak the language. This instrument fulfills its job when it is read because the health personnel will know what it has been said beforehand. The aim is to read what it is written using the alphabet, so the sentence might be said by the interlocutor.

Therefore, a practical instrument was developed as a manual that may facilitate the clinical interview and the medical recommendations. Both, the interview and the recommendations are normally carried out by the doctor on the patients (Willis Hurst, 1998). Based on the experience of the doctors, they were asked about their most common recommendations that they normally give to their patients.

The aim of this paper is to support the health personnels who work in $\mathrm{Na}$ huatl-native-speaker communities, so they can make the clinical interview and the medical recommendations. The instrument is not only developed for the health personnels, but also for us to have a bridge of communication with them. The background of this paper is the report of (Alvarez et al.; 2015) in which a clinical interview was already developed in Nahuatl. 


\section{Nahuatl}

There are many reduced locations "more than 188 thousand locations with no more than 2.5 thousand inhabitants. They represent $98 \%$ of the total amount of locations in the country. In these locations, less than the fourth part of inhabitants live (23\%). This population concentration has been part of the history of Mexico" (CONAPO, 2012). SO, Mexico has more than 1,725,620 Nahuatl speakers until October 2017. (INEGI ${ }^{1}$, count me). We must be treated acknowledging our legitimacy.

The knowledge of Nahuatl was necessary for this guide. We acknowledge Priest Horacio Carochi who wrote his book Compendio del Arte de la Lengua Mexica (Compendium of the Art of the Mexica Language) in 1645. Nahuatl is based on a respectful communication; it has two meanings which are not opposite but integrated: the polite language and the reverential language. The reverential language is the most respectful; it means devotion, respect, and esteem. It means devotion since some sentences, represented in alphabetic grammar structures, add ideas in one single word in contrast with Spanish in which it is required more than one word. For example, the following sentence, you will go with her, will be translated into both languages: polite and reverential. Enunciating the phonemes is of utmost importance in Nahuatl. In polite language, the example would be Tichuicaz (you with him or her, will go) i.e. Ti means "you"; c means "to him or her": object pronouns; hui means "to go"; z means "will”. Using the same sentence in the reverential language, the translation would be $T e$ huatzintimoquihuiquili (you ${ }^{2}$ will go with him or her). Tehuatzin means you in a reverential way; timo means yourself; qui means with him or her, the direct object ${ }^{3}$; hui means to go (huica); quili is a morpheme that goes with the verb huica. It is used in reverential language. The reverential language is more difficult particularly when reflexive pronouns are used. Reverential language adds tzinoawhose "a" is eliminated due to phonaesthetics. So, tzino remains. Moreover, in Nahuatl first-person singular (I) and plural (we) are not expressed in reverential language because it implies arrogance.

However, and insofar as the need of the instrument to enable a better communication between the health personnel and the Nahuatl speakers, it is of utmost importance to omit the reverential language since it will complicate Nahualt even more as this project developed a model in which this phonetic language was shaped into Spanish grammar. Be that as it may, reverential language will be used only if the patient is acknowledged by the community as an important member. In this specific case, the ticitl (doctor), since s/he is interested in the patient's health, may use this language to communicate.

"When someone interacts with another person emotionally, and this person coemotes harmoniously with him or her; they move together as they listen to each other, s/he is moving in the way of thinking of the other one. It is impor-

\footnotetext{
${ }^{1}$ National Institute of Statistics and Geography (Mexico).

${ }^{2}$ In formal discourse.

${ }^{3}$ According to Spanish grammar.
} 
tant to understand what s/he is saying. Moreover, if the other person wants to listen to the other one, it must be reciprocal. Otherwise, s/he will only listen to him/herself" (Maturana, 1997: p. 62).

Nahuatl is an agglutinative language meaning that its interpretation and application are difficult. Even though there have been studies for its interpretation using Spanish grammar, those studies are incomplete since it is a tone language.

"Nahuatl is an agglutinative language, i.e., it is a language that it joins two or even more morphemes with roots in order to create a new word".

"A noun can be joined to other nouns or verbs. Verbs can be joined to other verbs. Moreover, affixes can be joined to any word to either create a new one or to change its original meaning" (Sullivan Thelma, 1976: p. 15).

This is the reason why this instrument to carry out the clinical interview and the medical recommendations is developed in polite language. Its aim is to look for simpler ways that enable a respectful communication between the health personnel and the Nahuatl community regardless the reverential language. Because reverential language is more complicated, it was decided to use the polite language so the communication would be easier. Based on the interpretative criteria such as our idea of fostering the identity elements we see, polite language was decided for this instrument. The reference "we" is insofar as it will help the health personnel in Nahuatl. They will be able to incorporate the reality, elements of identity that enable to acknowledge the behavior in "we". Do not forget that "we" is seen as arrogance: this reproachable behavior, according to Nahuatl, is seen in the interaction where it is not used in the reverential language nor the first-person singular (I). Since the purpose of this instrument is to facilitate communication; a personal, professional, respectful intention is required. If we do not follow this model, dialogue will be impossible. The expected dialogue will lead the health personnel to a dedicated, interesting, and human communication in his/her job following ethics and aesthetic principles.

It is important to read slowly when the words are pronounced, so the enunciation of all the elements would be clear because Nahuatl is an agglutinative language, and it has different morphemes that create ideas. So, this guide includes 1) questions, specifications or recommendations in Spanish;2) the Nahuatl translation; 3) the morphemes translations below the Nahuatl word between parenthesis and in smaller letters. The morphemes that create a new word are separated between dashes (-) for an easy pronunciation. These are the reasons they need to be read slowly: for a better pronunciation. So, it is strongly recommended to practice the pronunciation before using the instrument. For practical purposes, we have to mention that: 1) "ll" is pronounced as a long "l" with a soft intonation; 2) Saltillo " $h$ " is pronounced with a soft exhalation of air in the glottis, just like the Spanish “j”.

Nahuatl is a beautiful language to hear. Its stressed vowel is the penultimate except for the vocatives and monosyllables whose last syllable is stressed due to its purpose of calling. These are created by adding the vowel "é" to the noun or 
proper name. The voice needs to be raised when the " $\mathrm{e}$ " is pronounced. In Spanish, "oh!" interjection is used. For instance, cihuatl means woman; cihuatle means "Oh, woman!"

\section{Research Methodology and Techniques}

The document was done using the variables of classical Nahuatl as well as the Nahuatl spoke in Zongolica Sierra, Veracruz, Mexico. These two variables are slightly different, so the instrument uses the classical Nahuatl. Despite this fact, there are other communities whose speakers have other variations of Nahuatl; therefore, this instrument is meant to work from the classical Nahuatl to any other variation of the language once the appropriate modifications are carried out.

For this document to work with the region of Sierra Zongolica, the procedure was to go to the Sierra where the instrument was developed. This instrument had the appropriate enunciations as well as the structures of classical Nahuatl used for this instrument. A first application was carried out for a clinical interview and for a medical recommendation with a group of bilinguals. In this part of the process, both the questions and the recommendations, which were not understood in Spanish, were read by the bilinguals that worked with us. The bilinguals were part of the health personnel (midwives or doctors). They were asked how could someone ask those questions or recommendations in Nahuatl. So, the unknown words of that variable were incorporated into the tool.

Once the variable elements of Nahuatl in Sierra Zongolica are acknowledged, we came back to a remote community. The instrument was tested with an illiterate population whose only language is Nahuatl. The clinical interview and medical recommendations were carried out on the target population with the assistance of bilingual midwives. The target population was illiterate and its only language is Nahuatl. Therefore, the guide was tested in assistance with bilingual midwives considering any necessary modifications so the Nahuatl speakers could understand.

The necessary calculation for the clinical interview, prescriptions, and medical recommendations were undertaken with scales that enabled to acknowledge intensity, frequency, and periodicity the Nahuatl numbers. Moreover, all the considered changes suggested by the health personnel were taken into account.

Furthermore, since we sought communicative elements apart from inquiry for the necessary prescriptions as well as the medical recommendations, we had to include a linguistic repertoire related to the clinical interview and medical recommendations. Hence, this document includes dictionaries of nouns and verbs, four lists of words: adjectives, adverbs, colors, smells, flavors, numbers hours, months, and years.

The instrument has the word in Nahuatl and the English elements between parenthesis. These elements are ideas in Nahuatl, so anyone can acknowledge and apply the structure of Nahuatl. 
It is important to mention that this instrument is based on the idea that the communication circle is made by a statement quema (yes) and a negation ahmo (no), so the clinical interview can be answered. The question is asked in Nahuatl and its meaning is known since it is written in Spanish as well.

Do you feel any pain?

Nahuatl of Zongolica

Another Nahuatl variation

1) Point the part of your body

2) Where is the pain located?

Nahuatl of Zongolica

Another Nahuatl variation

¿How much does it hurt?

1) A lot

2) A little

Nahuatl of Zongolica

Another Nahuatl variation

Is your body swelling?

Nahuatl of Zongolica

Another Nahuatl variation

1) Where is the swelling?

2) Point your body

Nahuatl of Zongolica

Another Nahuatl variation

Since when do you have the swelling?

Nahuatl of Zongolica

Another Nahuatl variation
¿Timo-cocoliz?

Timo (you, subject pronoun) cocoliz (pain, of cocoliztli)?

1) Timo-mapilhuia in mo-nacayo-uh Timo (you, subject pronoun) mapilhuia (point with the finger) in (in)mo (your, possessive adjective) nacayo (body) uh (genitive)

2) ¿Campati-pia-cocoliz?

¿Campa (where) ti (you, object pronoun) pia (have) cocoliz (pain, cocoliztli)?

$¿$ Quechquichtimo-cocoliz?

¿Quechquich (how much) timo (you, subject pronoun) cocoliz (pain, ofcocoliztli)

1) Miac

Miac (a lot)

2) Ahmomiac

Ahmo (no) mica (a lot)

¿Timo-pozahuamo-nacayo?

¿Timo (you, subject pronoun) pozahua (swelled) mo (your, possessive adjective) nacayo (body)?

1) ¿Campatimo-pozahua? ¿Campa (where) timoyou, subject pronoun) pozahua (swelling)?

2) Timo-mapilhuiamo-nacayo Timo (you, subject pronoun) mapilhuia (point with your finger) mo (your, possessive adjective) nacayo (body)

¿Inicicuacti-pia-pozahua? ¿Inic (since)icuac (when) ti (you, subject pronoun) pia (have) Potzahua (swelling)?

This chart is based on Spanish grammar, and in some cases, Spanish grammar is completely different from English grammar. Therefore, some words may seem not to make sense.

This is an example of the clinical interview done in the variable of Nahuatl of sierra Zongolica, Mexico. There are a lot of spaces for any other variables since this instrument has incorporated the mechanism and logic of the instrument, this means, that the new variables can be added. 


\begin{tabular}{|c|c|}
\hline & ¿O-timo-cuetlaxihui? \\
\hline \multirow{2}{*}{ Have you passed out? } & ¿O (past tense) timo (you, subject pronoun) \\
\hline & cuetlaxihui (passing out)? \\
\hline \multirow{2}{*}{ Nahuatl of Zongolica } & ¿Tech-cuetlaxihui? \\
\hline & $\begin{array}{l}\text { ¿Tech (to us, object pronoun) cuetlaxihui (passing } \\
\text { out)? }\end{array}$ \\
\hline Another Nahuatl variation & $\begin{array}{l}\text { It is interesting to see how the social referent is not } \\
\text { mentioned in singular. }\end{array}$ \\
\hline \multirow{2}{*}{ Since when have you started passing out? } & ¿Inicicuactimo-cuetlaxihui? \\
\hline & ¿Inic (since) icuac (when) timo (you, subject \\
\hline \multirow{2}{*}{ Nahuatl of Zongolica } & pronoun) cuetlaxihui (passing out)? \\
\hline & ¿Inicicuac tech-cuetlaxihu? \\
\hline \multirow{2}{*}{ Another Nahuatl variation } & ¿Inic (since) icuac (when) tech (us, direct object) \\
\hline & cuetlaxihui (passing out)? \\
\hline
\end{tabular}

This chart is based on Spanish grammar, and in some cases, Spanish grammar is completely different from English grammar. Therefore, some words may seem not to make sense.

¿Timo-itic-mo-nacayo-tla-hueya-zonehua? ¿Timo (you, subject pronoun) itic (inside) mo

Have you felt as if something is growing inside (your, possessive pronoun) nacayo (body) tla your body? (lumps) (something) hueya (id growing) zonehua (to stick)?

Nahuatl of Zongolica

Another Nahuatl variation

¿Timo-itic-mo-nacayo-tilini?

¿Timo (you, subject pronoun) itic (inside) mo (your, possessive pronoun) nacayo (body) tilini (be tighten)?

1) ¿Campa timo-hueya-liztli?

1) Where is the lump? $¿$ Campa (where) timo (you, subject pronoun) hueya (growing) liztli (act of)

2) Point your body

2) Timo-mapilhuiamo-nacayo

Timo (you, subject pronoun) mapilhuia (to point)

Nahuatl of Zongolica mo (your, possessive pronoun) nacayo (body)

1) Where do you have the lump?

2) Point your finger

1) ¿Campa ti-pia-itic-tilini? ¿Campa (where) ti (your, possessive pronoun) pia (have) itic (inside) tilini (be tight)?

Another Nahuatl variation

2) Timo-mapilhuiamo-nacayo Timo (you, subject pronoun) mapilhuiato point) mo (possessive pronoun nacayo (body)?

This chart is based on Spanish grammar, and in some cases, Spanish grammar is completely different from English grammar. Therefore, some words may seem not to make sense.

The medical recommendations and the clinical interview in Nahuatl are based on the grammar structure of classical Nahuatl. In this document, a variable of Nahuatl spoken in sierra Zongolica, Veracruz is presented. So, if there is a case, space is left for another incorporation. The procedure used for the medical recommendations was to interview the health personnel of different specialties. These specialties are the most important regarding the first contact in the medi- 
cal consultation. Once the health personnel were aware of the aim of this instrument and accepted the interviews, they were asked about the common medical recommendations they gave. We translated their recommendations into classical Nahuatl and they were proved in the Nahuatl population of Zongolica, Veracruz.

We worked with bilingual general doctors who work in the same community particularly in childbirth. We told the doctors the medical recommendations in Nahuatl, as we wrote them, to gather information. After it, the doctors of the community told us what they had understood. If they understood what we just said, the grammar structure would not change. If it was not understood, we would have asked: how could we express what we want to say. This is how we developed the medical recommendations in the variable of Nahuatl of Zongolica, Veracruz.

The guide was restructured with the ethnographic records: field notebooks and recordings. We came back again to the field after the incorporation of the ethnographic material. The guide was tested with a monolingual-Nahuatl adult. Thus, we got the validation of the final document.

The chosen words for the repertoire regarding the clinical interview were checked in around seven dictionaries. This process was easier thanks to the Compendio Enciclopédico del Náhuatl (Encyclopedic Compendium of Nahuatl). The Compendium is a program that enables the access of multiple dictionaries of Nahuatl. "The great dictionary" has 19 dictionaries the 1547 dictionary of brother Olmos, 2002 with Mecayapan dictionary. Its geographic origins are from western Mexico (Guadalajara) to the eastern (Veracruz) including the center of Mexico (Compendio Enciclopédico del Náhuatl, 2009: p. 9).

There were also other dictionaries we consulted, such as Carbó, 2012, Nahuatl Verb Dictionary. Molina, Alonso, Spanish/Mexican Vocabulary. Remi Simeon; Nahuatl or Mexican Dictionary. Spanish Freelang Dictionary-ancient Nahuatl. Eutiquio Jeronimo, et al.; Tlahtolnechikolli Dictionary Modern Nahuatl-Spanish of Zongolica Sierra. Finally, the word lists in Nahuatl of Medina Ramos, Genaro; Nahuatl book.

The words chosen for the repertoire with respect to the clinical interview were verified in about seven dictionaries. This process was made easier thanks to the Compendio Enciclopédico del Náhuatl (2009). It is a program that allows access to multiple Nahuatl dictionaries that contain 19 dictionaries; the dictionary made in 1547 by Olmos (2002). There were also other consulted dictionaries, such as Portugal Carbó (2012); Molina, Alonso, Spanish/Mexican vocabulary (2008). Remi Simeon, Nahuatl or Mexican dictionary (2007). Freelang Dictionary in English: Old Nahuatl (s/f). Eutiquio Jerónimo, et al., TlahtolnechikolliNahuatl-Spanish Modern Dictionary of Zongolica Sierra (2004). Medina Ramos, Genaro Nahuatl book (1999).

\section{Results}

\subsection{Clinical Interview}

It is important to acknowledge the difficulty of Nahuatl, especially in the listen- 
ing, in order to do the clinical interview in the language. The clinical interview is carried out with questions that enable the health personnel, who do not speak Nahuatl, to do the clinical diagnosis. The questions are done by the health personnel (sender) who doubles as the referrer that sends the message to the patient (receiver). Then, the receiver can answer yes (quema) or no (ahmo). If further information is required, the health personnel will request to the patient to show him/her the part of the body that is in pain. Therefore, this document shows the patient how the clinical interview will be carried out.

\begin{tabular}{|c|c|}
\hline I will ask you. & Ni-mitz-tlatlani-z \\
\hline Nahuatl of Zongolica & $\mathrm{Ni}$ (I subject pronoun) mitz (you, direct object) \\
\hline \multirow[t]{2}{*}{ Another Nahuatl variation } & tlatlani to ask) z (will) \\
\hline & Ihuanti-nech-nanquili-z \\
\hline And you will answer me & $\begin{array}{l}\text { Ihuan (and) ti (you, subject pronoun) nech (me, } \\
\text { direct object) nanquili(contestar, de nanquilia) } Z\end{array}$ \\
\hline \multirow[t]{2}{*}{ Nahuatl of Zongolica } & (futuro) \\
\hline & Ti-tech-nanquili-z \\
\hline Another Nahuatl variation & $\begin{array}{l}\mathrm{Ti} \text { (you, subject pronoun) tech (us, direct object) } \\
\text { nanquili (answer) z (will) }\end{array}$ \\
\hline Yes & Quema \\
\hline No & Ahmo \\
\hline And when I want to know & Ihuanicuacnino-nequi-machti-z \\
\hline & Ihuan (and) icuac (when) nino (I, subject \\
\hline Nahuatl of Zongolica & pronoun) nequi (want) machti (to know, \\
\hline Another Nahuatl variation & machtia) z (will) \\
\hline Point in your body & Timo-mapil-huia-z mo-nacayo-uh \\
\hline & Timo (you, subject pronoun)mapil (finger) huia \\
\hline Nahuatl of Zongolica & (action) z (will) mo (your, possessive adjective) \\
\hline Another Nahuatl variation & nacayo (body) uh (genitive) \\
\hline
\end{tabular}

This chart is based on Spanish grammar, and in some cases, Spanish grammar is completely different from English grammar. Therefore, some words may seem not to make sense.

Regarding the scales of intensity, frequency, and periodicity in Nahuatl numbers, the necessary calculations will be carried out for dialogue, prescriptions, and the recommendations that the health personnel require. They can look up in the dictionaries and the compendium at the end of the document. The Nahuatl number system is vigesimal, i.e. there are only 20 cardinal numbers and ten more; the total is 30 . These 30 correspond to the days of the month. Moreover, we will see the nomination of the hour, day, week, month, and year in the following question: how long... (hours, days, weeks, months, or years).

The instrument bases the clinical interview development on the general population and patients. So, different types of clinical interviews were reviewed in order to choose the best one in structure (Willis Hurst, 1998).

Clinical interview chapter in Nahuatl starts with the statements for the health personnel. It introduces the doctor's and patient's presentations later on. Moreo- 
ver, it will also present the agreements to establish the interaction between the doctor and the patient through the statements for the communication circle. These statements might be on behalf the patient with yes (quema) or no (ahmo) or by pointing a part of his/her body. It is done in this way due to tithe difficulty of the language.

The document includes: Introduction; Clarification of the clinical interview; Numbers: days, hours, months, and years; Clinical interview: Introduction, patient information, explanation to the patient on how the instrument works; Background, beginning of the interview to acknowledge of the disease; Interview of the systems, i.e. respiratory system, digestive system, cardiovascular system, renal and urinary system, reproductive systems: male and female, endocrine system, hematopoietic and lymphatic system, skeletal and muscular systems, nervous system, sense organs, psychic sphere, and general symptoms.

\subsection{Medical Recommendations in Nahuatl}

This section is for the medical recommendations in Nahuatl. We must be aware that Nahuatl is a living tongue. It does not require a subject for interaction nor pronouns because both are implied. Therefore, the communication is simpler regarding space and time. So, the arrangement of the recommendations in $\mathrm{Na}$ huatl is only for healthcare systems that will enable the communication as well as the interactions. Since this instrument may help the communication through language, the elements of our identity build the reality. Communicating with others enriches human coexistence. "We are in the language when we move coordinately no matter the direction. 'Languaging' happens in life along with thrilling: together is what I call talking” (Maturana, 1997: p. 42).

In this part of the document, the most frequent recommendations are found regarding the main instructions of the health personnel. These recommendations are arranged according to the specialty. So, Medical Recommendations in Nahuatl section is arranged by the following areas: Gastroenterology, Endocrinology, Pneumology, Allergology, Gynecology, and Cardiology.

This chapter structures its functioning through a simple mechanism. It implies to be aware of what it is meant to say before speaking in Nahuatl. It is written in English and in Nahuatl for understanding. The elements were separated with dashes for a better reading. For example, titlacua $=t i-t l a-c u a$ means "you eat. $T i$ (you), tla (something) cua (to eat). Any recommendation or clinical interview in Nahuatl are shown with their morphemes and meaning of the words.

Example of the medical recommendations in Nahuatl section:

\begin{tabular}{ll}
\hline & Ahmoti-cua-z tleintimo-cocoa \\
Domo not eat what it is not good for you & $\begin{array}{l}\text { Ahmo (you, subject pronoun) cua (to eat) } \\
\mathrm{Z} \text { (will) tlein (something) timo (you, subject } \\
\text { pronoun) cocoa (disease) } \\
\text { Ahmo xi-cua-z tleinmitz-coco-ba } \\
\text { Nahuatl of Zongolica }\end{array}$ \\
Ahmo (no) xi (imperative) cua (to eat) $\mathrm{z}$ (will) \\
tlein (something) mitz (you, object pronoun) \\
coco (disease cocoa) ba (possessive, hua)
\end{tabular}




\section{Continued}

\begin{tabular}{ll}
\hline & $\begin{array}{l}\text { Ti-c-chipahuai-yacamo-cone-uh } \\
\text { Ti(you, subject pronoun) c (object pronoun } \\
\text { him/her) chipahua (to clean) i (his/her possessive } \\
\text { adjective) yaca (nose, yacatl) cone (child, conetl) } \\
\text { uh (possessive) }\end{array}$ \\
Clean your child's nose & $\begin{array}{l}\text { Xi-yaca-popobamo-cone } \\
\text { Xi (imperative) yaca (nose yacatl) popoba (to } \\
\text { clean, popoa) mo (you, possessive adjectives) } \\
\text { cone (child, conetl) }\end{array}$ \\
Another Nahuatl variation & Ximo-ihiyoti-ipotoc \\
Ximo (you, subject pronoun) ihiyoti (to breath \\
hiyotia) ipotoc (steam)
\end{tabular}

This chart is based on Spanish grammar, and in some cases, Spanish grammar is completely different from English grammar. Therefore, some words may seem not to make sense.

\section{Conclusion}

The Nahua indigenous language-speaking communities that live in the Zongolica sierra in Veracruz, Mexico, are marginal groups that live in conditions of extreme poverty and isolation, a result of the colonization that has come since the Spanish conquest and has continued on the part of the national state that has not developed the public policies that allow its integration to the processes of social development, which should not weaken the strengthening of its language, which is in any case a wealth not recognized by the Mexican state. In this context, mechanisms have not been created that allow health care to be in accordance with what is established in national legislation, which indicates the right that Mexicans have to communicate in the language of which we are speaking, in any field, both public and private.

Thus, the instrument "clinical history and medical recommendations in the Nahuatl language" facilitates the interaction between health personnel and the native Nahuatl-speaking population by being able to implement communication without speaking the Nahuatl language, since it has been structured on the basis of the grammar of Spanish, so this language can be read to be able to communicate without being a Nahuatl speaker, knowing in advance what is meant. The 
clinical questioning was constructed by translating the one that we consider the best clinical questioning that is used in medical practice, and that is that of the internists, which was restructured so that the cycle of communication was completed with the affirmation burning (if) or ahmo (no), since the complexity of this language increases when it is listened to. In the section of medical recommendations, these were translated and do not require the patient's response to be the indication of what should or should not be done, depending on their pathology, which part of the instrument was structured with the recommendations that the Clinical doctors perform in their daily consultation, so that for this purpose, we interviewed clinicians from the following specialties: Gastroenterology, Endocrinology, Pulmonology, Allergology, Gynecology and Cardiology.

The instrument has already been tested in the field and the response, both from the population to whom the instrument is directed, as well as from the doctors who treat them, and has been favorable, since on the part of the Nahuatl indigenous population, the disposition was registered to understand what the health personnel tries to communicate, recognizing the effort that this implies, and on the part of the health workers, their evaluation is helping them to solve a serious problem they have to perform in their work, which, without adequate communication, it cannot be done. This also leads to overcome the well-founded doubt of working with translators who are not experts in this activity, since it is not certain whether the translator transmitted what he asks in the clinical interrogation or was said as a medical recommendation.

The document covers another of its objectives, which is to build a communication bridge that allows modifying the identity construction of the subjects by recognizing and recognizing themselves as authentic and legitimate subjects, and without this, the dialogue allows the respectful interaction between the men.

\section{Acknowledgements}

Superior School of Medicine, Instituto Politécnico Nacional, Mexico. Reg. SIP No. 20181970, y Reg. SIP No. 20181294.

\section{Conflict of Interest}

The authors state that we do not have any conflict of interest.

\section{References}

Alvarez, L. et al. (2015). Guía para el Interrogatorio Clínico en Lengua Náhuatl. México: Instituto Politécnico Nacional.

Compendio Enciclopédico del Náhuatl. (2009). México: Instituto Nacional de Antropología e Historia.

Eutiquio Jerónimo, et al. (2004). Tlahtolnechikolli Diccionario Nawatl Moderno, Español de la Sierra de Zongolica Ver. México: Jalapa Veracruz.

Freelang Dictionary in English: Old Nahuatl (s/f). Náhuatl antiguo, de acceso libre.

Henestrosa, A. (1993). Dos Lenguas Un Mundo. México: Lotería Nacional para a Asisten- 
cia Pública.

Maturana, H. (1997). El sentido de los Humano. Chile: J. C. Editores.

Medina Ramos. (1999). Genaro, Náhuatl. México: Puebla, Cholula.

Molina, A. F. (2008). Vocabulary of the Castilian/Mexican and Mexican/Castellana Language (1st Ed. 1555-1571). Mexico: Ed Porrua.

Olmos, F. A. (2002). Arte de la Lengua Mexicanaa (Primera Edición, 1547). México: Universidad Autónoma de México.

Portugal Carbó, E. (2012). Diccionario de verbos de la lengua Náhuatl. México: Editorial Porrua.

Remi Simeon. (2007). Diccionario de la lengua náhuatl o mexicana. México: Siglo XXI.

Sullivan Thelma, D. (1976). Compendio de Gramática Náhuatl. México: UNAM, Instituto de Investigaciones Históricas.

Willis Hurst, J. (1998). Medicina para la práctica clínica. Argentina: Médica Panamericana. 